\title{
Developing attributes and levels for a discrete choice experiment on basic health insurance in Iran
}

\author{
Ali Kazemi Karyani ${ }^{1}$, Arash Rashidian*2, Ali Akbari Sari ${ }^{3}$, Sara Emamgholipour Sefiddashti ${ }^{3}$
}

\section{Abstract}

Background: Nonmarket stated preferences valuation, especially discrete choice experiments (DCEs), is one of the commonly used techniques in the health sector. The primary purpose of this approach is to help select attributes and attributes-levels that are able to properly describe health care products or services. This study aimed at developing attributes and attributes-levels for basic health insurance system in Iran.

Methods: This study was conducted in 3 phases. First, narrative review was performed to identify related attributes. Also, 9 experts were interviewed to identify relevant attributes of health insurance in context. Other 36 experts rated the attributes and levels. Then, the research team decided on the inclusion of attributes and levels in the final design. The design was constructed using generic and Defficient method with SAS 9.1. The design was divided into 3 blocks, each having 8 choice sets. Finally, the choice set was piloted with 45 participants.

Results: Public hospitals, and private hospitals benefits, dental insurance coverage, inpatient benefits, rehabilitation therapy, and paraclinical benefits, long-term care, medical devices benefits (Ortez, Protez, etc.), and monthly premium were identified and included in the final attribute design (D-efficiency $=98.16$ ). The pilot study revealed that participants could easily understand and answer all the choice sets.

Conclusion: The results of our study indicated that health insurance service benefit packages and premium were among the most important attributes that need to be included in the final attribute design for Iranians. The policymakers and health insurance organizations should emphasize these attributes in the benefit packages to make improvements. The emphasis on these attributes can help elicit people's preferences and willingness to pay for attributes.

Keywords: Discrete choice experiment (DCE), Conjoint analysis, Attributes, Attribute-levels, Health insurance, Iran

Copyright $@$ Iran University of Medical Sciences

Cite this article as: Kazemi Karyani A, Rashidian A, Akbari Sari A, Emamgholipour Sefiddashti S. Developing attributes and levels for a discrete choice experiment on basic health insurance in Iran. Med J Islam Repub Iran. 2018(28 Mar);32:26. https://doi.org/10.14196/mjiri.32.26

\section{Introduction}

Health professionals and policymakers often need to evaluate and value the outcomes of a procedure or an intervention to select from alternative procedures and policies $(1,2)$. For a successful medical procedure or intervention, the health policymaking process should involve assessment of patients' and other stakeholders' preferences. The inclusion of partners' preferences can improve adherence to the procedures, and thereby, contributes to the success of the health policy (3-5). The stat-

Corresponding author: Dr Arash Rashidian, arashrashidian@gmail.com

1. Research Center for Environmental Determinants of Health, Kermanshah University of Medical Sciences, Kermanshah, Iran.

2. Department of Health Management and Economics, School of Public Health, Tehran University of Medical Sciences. Tehran, Iran.

3. Department of Health Management and Economics, School of Public Health, Tehran University of Medical Sciences. Tehran, Iran. ed preferences is a popular method for eliciting preferences and willingness to pay (WTP) for goods and services that do not have any market (6). Since most health goods and services are nonmarketable, today using nonmarket preferences valuation is a common technique in the health sector (7-9).

One of the most popular methods to value and elicit stakeholders' preferences is the discrete choice experiment $(\mathrm{DCE})(4,10)$. In recent years, this method has been

$\uparrow$ What is "already known" in this topic:

There are some studies about willingness to pay for health insurance in Iran. However, we do not have any evidence about the preferences of people for attributes of health insurance.

$\rightarrow$ What this article adds:

The first step to elicit preferences about health insurance is determining attributes and attributes-levels of health insurance. This study extracted attributes and attributes-levels of health insurance for Iran using a systematic approach. These attributes can help elicit preferences of people and policymakers, etc. in future studies. 
commonly used in the health sector $(11,12)$. Also, it has been used in evaluating preferences in screening methods $(13,14)$, prevention programs such as vaccination (15), treatment of diseases (16), rehabilitation methods (17), prioritization of health programs, decision-making (18), and health insurance (19). However, this is a new method to the health sector of Iran and has been used in very limited studies that focused on preferences of health experts, such as general practitioners and specialists (20-22). There is no market for basic health insurance. Therefore, it is often impossible to evaluate consumers' preferences about insurance markets (23). There is no enough evidence on people's preferences about basic health insurance in Iran. Meanwhile, having proper information on people's preferences about health insurance attributes and their willingness to pay is essential for determining the premium, designing a health insurance plan, and decision-making on reform and development of health insurance (24-26).

The basic assumption in DCE method is that any product, service, or intervention can be described by its attributes, and its value depends on the levels of the attributes (27). Thus, the first step in this method is to select attributes and their levels that can describe the product or service. This step is believed to be one of the most critical steps in designing studies (28). The attributes and levels can be identified by various techniques such as literature review, focus groups discussion (FDG), interview and experts' panel, or a combination of these methods (2729). Also, using qualitative methods to extract comments and views of potential beneficiaries is also a recommended method to determine the attributes and levels $(28,30)$. This, study aimed at developing attributes and levels of attributes to elicit health insurance preference of people in Iran.

\section{Methods}

This research was conducted in different phases. In the first phase, a narrative review was performed to identify a primary list of attributes. PubMed ScienceDirect, and Google Scholar databases were searched using a combination of commonly used keywords related to the topic of conjoint analysis and people's preferences of health insurance. The keywords used for the search were as follow: discrete choice experiment(s), discrete choice model, conjoint analysis, conjoint measurement, conjoint studies, conjoint choice experiment(s), stated preference, preferences elicitation, design feature, health, and health insurance $(7,23)$. The references of the relevant studies were also assessed to access eligible literatures.

All articles, reviews, and dissertations that were published in English from 1980 to 2015 in the databases were assessed. Also, documents related to the same research were considered as one. The main objective of the literature review was to find a list of attributes and levels of health and health insurance preferences that were used in similar studies because the attributes can be potentially implemented for the DCE study. The emphasis was on the attributes of health insurance, especially benefits packages, services, and premium. These characteristics can have an important role in consumers' choice of health insurance (31). Quality of the studies was assessed using the checklist for conjoint analysis applications in health care (4). After reviewing the included studies, lists of health insurance attributes related to the Iranian insurance were selected. The attributes, such as amount of deductible, choice of family physicians, second opinion, and unit of enrollment (individual/core nuclear family/entire extended family), were excluded from the analysis because they were not related to list of attributes in the Iranian health insurance systems.

In the second phase, the opinions of health insurance experts (key informants) were obtained using a semistructured interview guide. A total of 9 experts from the Social Health Insurance (SHI) and Iranian Health Insurance (IHI) in Tehran, who were believed to be well- informed about the challenges and expectations of the insured, were involved in the interview. The inclusion criterion was having a minimum of 5 years of work experience related to health insurance.

The sample size was determined by a saturation criterion using a snowball sampling technique (32). The interviews were conducted in September and October 2015 and were tape-recorded. Interview questions were designed in such a way that experts were indirectly asked about the attributes of health insurance. The content of the questions were about the perceived features of an ideal health insurance, strengths and weaknesses of the current health insurance, important factors affecting WTP for health insurance, covered services, reforming requirements of current health insurance, and people's expectations from their health insurance. The services provided for the insured were also emphasized. After completing the interviews, important characteristics of health insurance were extracted.

In the third phase, a candidate list of attributes from the previous steps was prepared. There were some limitations in the number of features (attributes) and levels, which was included in the final design of the DCEs study $(7,27)$. Therefore, these attributes and attributes levels were prioritized and rated by the opinion of 36 experts. Each attribute was rated using a scale of 1 to 5 , with 1 indicating the lowest score and 5 the highest score. The scores of each feature were summed up to obtain an overall score and rank. The experts further prioritized the levels of attributes using a checklist consisting of 4 to 7 options for each attribute. The experts were asked to select 3 options out of the options provided. Then, the responses for each level were summed up to determine the levels of each attribute. Based on the objective of the study and lessons from previous works, the research team further synthesized and summarized the final levels of attributes $(7,27)$. The levels of premium, as one of the final attributes, were selected according to a previous study (25), based on inflation rate and the average of current premiums in the country. Also, premium levels were determined in the range that embraced minimum, average, and maximum possible premiums.

Finally, D-optimal generic design (D-efficient) was developed with a $24-$ choice set. The choice set was divided 
into 3 blocks, each having 8 choice sets. Each choice set had 2 alternatives. The design was efficient under the null hypothesis $\beta=0$. Also, we included an easy and dominant choice set for warm up and test consistency of the choices and check the understanding of samples. In this choice set, one of the 2 profiles was better than its alternative. The questions on demographic, socioeconomic, and health status were added to the choice set, and the questionnaire was piloted on 45 insured interviewees (each 15 persons were presented with one type of the questionnaire). The pilot study helped to determine the clarity and appropriateness of the choice set and the understandability of the choice set (27).

\section{Results}

Review

In this study, 11 documents were reviewed and reported different methods to select attributes of health insurance (Table 1). The most commonly used methods were FGD $(19,33-36)$, review of literatures $(31,34,35,37)$, and expert interviews $(6,19,35)$. Moreover, other studies used more than 1 method to select the final attributes $(19,34$, $35)$. The minimum and maximum number of attributes reported were 2 (31) and 12 (37), respectively. All the studies included premium/cost as a final attribute except in 1 study (37). "Copayment" was an attribute mentioned in 4 of the studies or documents $(19,36-38)$, while "de-

Table 1. A summary of the included studies from the literature review

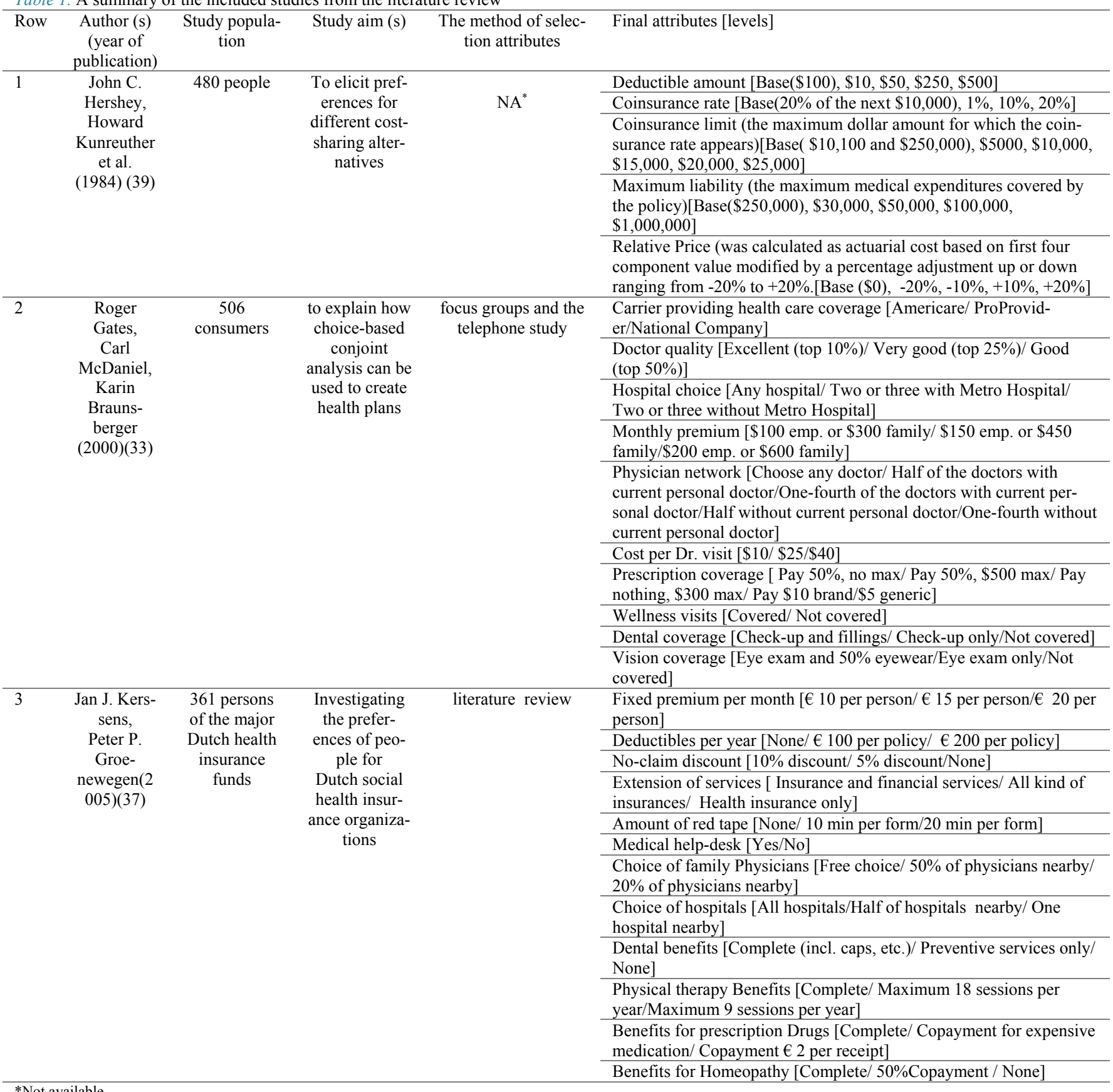




\begin{tabular}{|c|c|c|c|c|c|}
\hline \multicolumn{6}{|c|}{ Table 1. Cntd } \\
\hline \multirow[t]{6}{*}{4} & \multirow{6}{*}{$\begin{array}{l}\text { Karolin } \\
\text { Becker and } \\
\text { Peter } \\
\text { Zweifel } \\
(2008)(38)\end{array}$} & \multirow{6}{*}{$\begin{array}{c}\text { A telephone } \\
\text { survey of } \\
1000 \text { people } \\
\text { aged }>24 \\
\text { years living in } \\
\text { the } \\
\text { German- and } \\
\text { French- } \\
\text { speaking parts } \\
\text { of Switzer- } \\
\text { land }\end{array}$} & \multirow{6}{*}{$\begin{array}{l}\text { To study the } \\
\text { relationship } \\
\text { between age } \\
\text { and WTP for } \\
\text { additional } \\
\text { choices in } \\
\text { Swiss social } \\
\text { health insur- } \\
\text { ance }\end{array}$} & \multirow{6}{*}{$\begin{array}{l}\text { attributes that are } \\
\text { currently under polit- } \\
\text { ical } \\
\text { debate were chosen }\end{array}$} & $\begin{array}{l}\text { Deductible [Status quo: SwF230, 400, 600, } 1200,1500 \text { per year/ } \\
\text { SwF0, 2400, } 4800 \text { per year] }\end{array}$ \\
\hline & & & & & $\begin{array}{l}\text { Co-payment[Status quo: } 10 \%(=0) \text { with a maximum of SwF600 } \\
20 \%(=1) \text { with a maximum of SwF1200] }\end{array}$ \\
\hline & & & & & $\begin{array}{l}\text { Alternative medicine [Status quo: some treatment methods are } \\
\text { covered }(=0) / \text { More alternative treatment methods are covered } \\
(=1)]\end{array}$ \\
\hline & & & & & $\begin{array}{l}\text { Medication[Status quo: all drugs on the list are reimbursed }(=0) / \\
\text { The cheapest product on the market is reimbursed }(=1)]\end{array}$ \\
\hline & & & & & $\begin{array}{l}\text { Access to innovation[Status quo: all treatment methods are cov- } \\
\text { ered as soon as they get approved }(=0) / \text { Innovative treatment } \\
\text { methods are covered only } 3 \text { years after introduction }(=1)]\end{array}$ \\
\hline & & & & & $\begin{array}{l}\text { Premium [Increase in the monthly premium by SwF } 50,25 \text {, or } \\
10 \text { / Decrease in the monthly premium by SwF50, 25, or } 10 \text { ( SwF } \\
=\text { Swiss franc)] }\end{array}$ \\
\hline \multirow[t]{3}{*}{5} & \multirow[t]{3}{*}{$\begin{array}{l}\text { Bernard } \\
\text { van den } \\
\text { Berg, Paula } \\
\text { Van Dom- } \\
\text { melen et al. } \\
(2008)(31)\end{array}$} & \multirow{3}{*}{$\begin{array}{l}631 \text { people in } \\
\text { two groups: } \\
\text { high risk } \\
\text { (with chronic } \\
\text { disease) and } \\
\text { low risk } \\
\text { (without } \\
\text { chronic dis- } \\
\text { ease) }\end{array}$} & \multirow{3}{*}{$\begin{array}{l}\text { to examine } \\
\text { preferences of } \\
\text { Dutch con- } \\
\text { sumers and to } \\
\text { evaluate trade- } \\
\text { offs between } \\
\text { various as- } \\
\text { pects of health } \\
\text { insurance } \\
\text { plans }\end{array}$} & \multirow[t]{3}{*}{$\begin{array}{l}\text { based on a prior } \\
\text { researches }\end{array}$} & $\begin{array}{l}\text { Quality of contracted care: } 1 \text {. Health after treatment [excellent } \\
\text { versus good/ very good versus good/ moderate versus good/ bad } \\
\text { versus good], 2. Your insurer reimburses prevention activities } \\
\text { [yes versus no], 3. Your insurer reimburses disease specific } \\
\text { activities [yes versus no] and } 4 \text {. Your care provider involves you } \\
\text { in treatment decisions [yes versus no] }\end{array}$ \\
\hline & & & & & $\begin{array}{l}\text { Quality of providing customer services: 1. Insurer's solving } \\
\text { complaints and questions [good versus bad], 2.Speed of reaction } \\
\text { of your insurer [good versus bad], 3. Ease of contacting your } \\
\text { insurer[good versus bad] and 4.Providing information through } \\
\text { your insurer [good versus bad] }\end{array}$ \\
\hline & & & & & Premium per year (euro)[950/1075/1200] \\
\hline
\end{tabular}

Table 1. A summary of the included studies from the literature review (continued)

\begin{tabular}{|c|c|c|c|c|c|}
\hline Row & $\begin{array}{c}\text { Authors } \\
\text { (year of } \\
\text { publication) }\end{array}$ & Study population & Study aim(s) & $\begin{array}{c}\text { The method of } \\
\text { selection attributes }\end{array}$ & Final attributes [levels] \\
\hline 6 & $\begin{array}{c}\text { Janet Mac- } \\
\text { Neil } \\
\text { Vroomen, } \\
\text { Peter Zweifel } \\
(2011)(40)\end{array}$ & $\begin{array}{l}1000 \text { people in } \\
\text { Germany and } \\
763 \text { respondents } \\
\text { in Netherlands }\end{array}$ & $\begin{array}{l}\text { to see whether } \\
\text { preferences be- } \\
\text { tween Germany } \\
\text { and Netherland } \\
\text { populations are } \\
\text { different and to } \\
\text { test the test the } \\
\text { presumption that } \\
\text { having a chronic } \\
\text { condition has a } \\
\text { different } \\
\text { influence on pref- } \\
\text { erences depending } \\
\text { on the country }\end{array}$ & $\begin{array}{l}\text { According to } \\
\text { contexts }\end{array}$ & 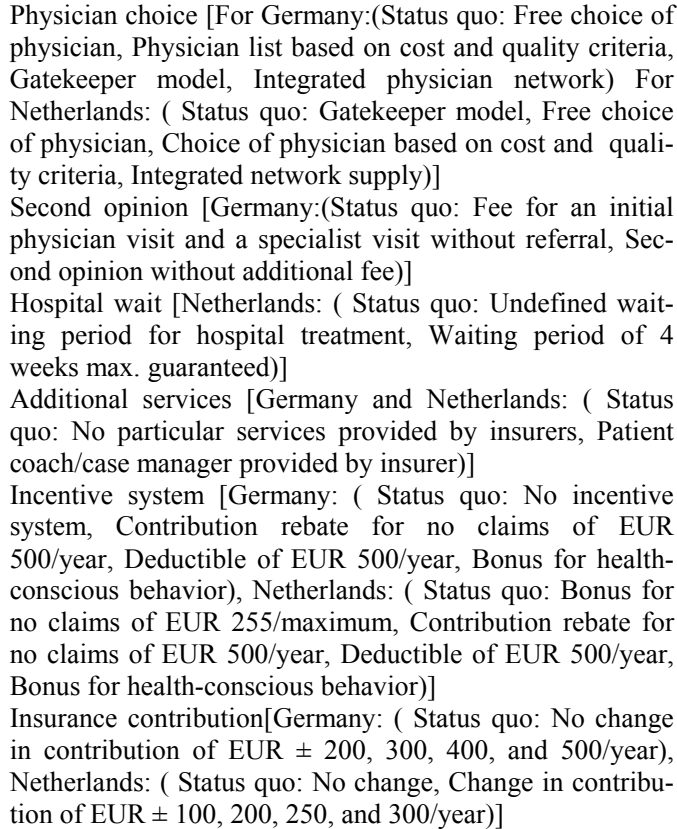 \\
\hline
\end{tabular}

ductible" was an attribute mentioned in 3 of the documents (37-39).

The attributes of coinsurance rate and coinsurance limit were reported in only 1 study (39). Studies also considered dental services $(33,37)$, physical therapy (37), longterm care (35), preventive/wellness care $(33,37)$, and paraclinical services (lab, X-ray, etc.)(19) in their final design. Moreover, 4 studies evaluated the insurees' preferences for drug benefit $(19,37,38,40)$. Furthermore, some of the studies considered quality of physician service (33,
34), contracted care, and services provided to customer (31) as attributes. Other attributes considered waiting time $(6,34,40)$, choice of hospital $(6,33,37)$, and choice of physician $(37,40)$ as attributes.

\section{Interviews}

Furthermore, a total of 9 experts were interviewed to identify health insurance attributes in Iran. Of the experts, 6 believed that health insurance should cover all health care services. The experts perceived that the people who 


\begin{tabular}{|c|c|c|c|c|c|}
\hline \multirow[b]{2}{*}{7} & Margaret E. & 1,431 respond- & To quantify the & a literature review, & Waiting time[30 minutes/ 2 hours/ 4 hours] \\
\hline & $\begin{array}{l}\text { Kruk, Peter } \\
\text { C. Rockers et } \\
\text { al. }(2011) \\
\text { (41) }\end{array}$ & $\begin{array}{l}\text { ents } \\
\text { in rural, northern } \\
\text { Liberia }\end{array}$ & $\begin{array}{l}\text { influence of health } \\
\text { system attributes } \\
\text { on preferences for } \\
\text { health clinics in } \\
\text { Liberia, }\end{array}$ & $\begin{array}{l}\text { discussions with } \\
\text { policy makers, de- } \\
\text { velop a candidate } \\
\text { list of attributes for } \\
\text { the DCE, Held four } \\
\text { focus groups to } \\
\text { reduce the number } \\
\text { of attributes and } \\
\text { determine levels }\end{array}$ & $\begin{array}{l}\text { Respectful treatment [Clinic workers respect } \\
\text { you/Clinic workers do not respect you] } \\
\text { Availability of medicines [Needed medicines are } \\
\text { always in stock/ Needed medicines are not always in } \\
\text { stock] } \\
\text { Quality of the physical exam [The nurse examines } \\
\text { you carefully/ The nurse does not examine you } \\
\text { carefully] } \\
\text { Cost [50 Liberian dollars/ } 200 \text { Liberian dollars/ } 500 \\
\text { Liberian dollars/ 1,000 Liberian dollars/ 1,500 Libe- } \\
\text { rian dollars] } \\
\text { Management [Government manages the clinic/An } \\
\text { NGO manages the clinic] }\end{array}$ \\
\hline 8 & $\begin{array}{c}\text { Anoo Nan- } \\
\operatorname{na}(2011)(6)\end{array}$ & $\begin{array}{l}1,200 \text { heads of } \\
\text { households from } \\
\text { five } \\
\text { districts who } \\
\text { were covered by } \\
\text { the Gold Card } \\
\text { scheme }\end{array}$ & $\begin{array}{l}\text { to elicit WTP for } \\
\text { public health } \\
\text { insurance (the } \\
\text { Gold Card } \\
\text { scheme) in Thai- } \\
\text { land }\end{array}$ & $\begin{array}{c}\text { Qualitative } \\
\text { Study (interview) }\end{array}$ & $\begin{array}{l}\text { An average waiting time for out-patient-Department } \\
(\mathrm{OPD})[15 \mathrm{~min} / 30 \mathrm{~min} / 45 \mathrm{~min}] \\
\text { Choice of hospitals [All public health care providers/ } \\
\text { All private health care providers/ All health care } \\
\text { providers] } \\
\text { Premium (per three months) }[100 \mathrm{Baht} / 300 \mathrm{Baht} / \\
500 \mathrm{Baht}]\end{array}$ \\
\hline 9 & $\begin{array}{l}\text { Papar Ka- } \\
\text { nanurak } \\
(2013)(35)\end{array}$ & $\begin{array}{l}300 \text { workers } \\
\text { under the Social } \\
\text { Health Insurance } \\
(\mathrm{SHI}) \text { scheme, } \\
\text { aged }>40 \text { years }\end{array}$ & $\begin{array}{l}\text { To } \\
\text { evaluation the } \\
\text { WTP for health } \\
\text { insurance after } \\
\text { retirement for } \\
\text { workers under } \\
\text { SHI in Thailand. }\end{array}$ & $\begin{array}{l}\text { in-depth interviews } \\
\text { with health insur- } \\
\text { ance agents, study- } \\
\text { ing health insurance } \\
\text { policies, and focus } \\
\text { groups with the } \\
\text { workers }\end{array}$ & $\begin{array}{l}\text { Outpatients healthcare expenses[3,000 Baht } \times 6 \\
\text { times per year (OPD1) / 5,000 Baht x } 12 \text { times per } \\
\text { year (OPD2)] } \\
\text { Inpatients healthcare expenses [100,000 Baht per } \\
\text { year (IPD1)/ } 300,000 \text { Baht per year (IPD2)] } \\
\text { Long- term care expenses [500 Baht per day (Maxi- } \\
\text { mum } 90 \text { days) (LTC1)/ } 1,000 \text { Baht per day (Maxi- } \\
\text { mum } 90 \text { days) (LTC2)] } \\
\text { Work compensation per day during hospital admis- } \\
\text { sion[1,000 Baht x } 20 \text { days per year (COMP1)/1,000 } \\
\text { Baht x } 45 \text { days per year(COMP2)] } \\
\text { Health insurance premium [500/ } 800 / 1,000 / 2,000 \\
\text { Baht per month] }\end{array}$ \\
\hline 10 & $\begin{array}{l}\text { Selma van } \\
\text { der Haar } \\
(2013)(36)\end{array}$ & $\begin{array}{c}101 \\
\text { women in rural } \\
\text { Nepal }\end{array}$ & $\begin{array}{l}\text { Estimation de- } \\
\text { mand for a health } \\
\text { cooperative pro- } \\
\text { gram in rural } \\
\text { Nepal }\end{array}$ & $\begin{array}{l}\text { Focus group discus- } \\
\text { sion, }\end{array}$ & $\begin{array}{l}\text { Premium (in NPR. per person per month) }[100 / 120 \\
/ 140] \\
\text { Co-payment for pharmacy (in percentage) }[10 / 20 / \\
30] \\
\text { Type of package[Individual/ core family/ extended } \\
\text { family] }\end{array}$ \\
\hline 11 & $\begin{array}{l}\text { Gilbert } \\
\text { Abotisem } \\
\text { Abiiro, Ale- } \\
\text { ksandra } \\
\text { Torbica et al. } \\
\text { (2014) (19) }\end{array}$ & $\begin{array}{l}814 \\
\text { household heads } \\
\text { and/or their } \\
\text { spouse(s) in two } \\
\text { rural districts }\end{array}$ & $\begin{array}{l}\text { To examine } \\
\text { preferences for } \\
\text { prospective micro } \\
\text { health insurance } \\
\text { (MHI) scheme }\end{array}$ & $\begin{array}{c}\text { Literature review, } \\
\text { Qualitative studies } \\
\text { (12 focus grouped } \\
\text { and } 8 \text { deep inter- } \\
\text { view) }\end{array}$ & $\begin{array}{l}\text { Unit of enrollment [ Individual/ Core nuclear family/ } \\
\text { Entire extended family] } \\
\text { Management [Bvumbwe SACCO/ An external } \\
\text { NGO/Community committee] } \\
\text { Health service benefit package[Basic: drugs only/ } \\
\text { Medium: drugs, lab tests/x-rays/ Comprehensive: } \\
\text { drugs, lab test/X-rays, and surgical Operations] } \\
\text { Copayment[50\% (half)/ } 25 \% \text { (quarter)/No copay- } \\
\text { ment] } \\
\text { Transport[No transport/ Only during referral and } \\
\text { emergencies/always: From home to health facility } \\
\text { any time sick] } \\
\text { Premium level per person per month[100 Malawian } \\
\text { kwacha (MWK)/300 Malawian kwacha (MWK)/500 } \\
\text { Malawian kwacha (MWK)] }\end{array}$ \\
\hline
\end{tabular}

paid premiums expect to receive the best service when they need them. In addition, the behavior of health care staff and quality of services provided by insurance organizations were considered important issues.

The experts stated that the high amount of out of pocket payment (OOP), especially for services from the private sector, was one of the main sources of dissatisfaction among the people with health insurance. Besides, the number of health care centers and quality of care provided by insurance organizations were supposed to be important factors. The current insurance organizations and/or their contracted providers were believed to have shortages of hospitals, hospital beds, and other health care centers,

such as clinics, laboratory facilities, etc.

The poor inpatient care in the public sector believed to insufficient to meet the inpatient care needs of people. The experts also reported that the limited insurance coverage to dental benefits, psychiatric services, infertility services, maternity, and screening tests were the weaknesses of the current benefit packages. Given the aging and prevalence of chronic disease in the recent year in Iran, The lack of long-term care was mentioned as an important benefit package that should be included in the insurance.

Some experts believed that the current premiums were considered higher than the fiscal capacity of people, while others stated that the premium was low for the basic in- 
surance. Yet, it was stated: "If the health insurance benefit packages were improved, people would pay higher premium to receive better services and quality care."

The experts considered the followings as service related attributes: the premium, health insurance coverage for inpatient services (in public and private sector), outpatient services, medical devices (such as Protez, Ortez, etc.), dental care, infertility treatment, and specific disease treatment, such as cancer. Furthermore, quality of the services, number of centers covered by insurance, long-term care including rehabilitation services, psychiatric services and counseling, and coverage for preventive services including screening and prenatal care were also the identified attributes. Another attributes identified were paraclinical services.

\section{Rating of attributes and levels}

A total of 26 candidate attributes were extracted from the review of the literatures and interview with experts. A total of 13 attributes were in common to both the document review and experts' interview; of them, 6 were included in the final design. The attributes such as cost per doctor visit, vision coverage, hospital waiting time, waiting time for outpatient visit, and transportation were identified from the literature review and were not included in the final design.

The attributes of public hospital benefits, inpatient benefits, medical devices benefits, and monthly premium attained the highest scores in rating. Two attributes of rehabilitation and paraclinical benefits were merged to improve the final design. After rating the levels and adjusting them based on the opinions of the research team, $60 \%$ and $90 \%$ levels of coverage were selected for the attributes of public hospital benefits and coverage of medical devices, respectively. Dental coverage was also found to have $40 \%$ and $70 \%$ levels of coverage of expenses. For another services benefit $50 \%, 70 \%$, and $90 \%$ coverage were selected as the final attribute-levels. The premium of 250 000, 350 000, and 450000 Iranian Rials were also the final levels of premium. The attributes that were included in the rating phase, the source and final decision about the inclusion in the final design and their levels are presented in Table 2.

\section{Initial design and piloting}

The design was constructed with generic and D-efficient method. The D-efficiency for our design was 98.16. A total of 20 iterations were used to improve the efficiency of the design (42). The pilot of the choice set revealed that all the participants (insured persons) understood the tasks, attributes, levels, and instructions. Also, all the participants correctly answered the warm up choice set. The average time taken to interview each insured person was about 12 minutes. Imaging or other methods for illustration of the final tasks were not needed.

\section{Discussion}

This study was the first attempt to develop attributes and attribute-levels of health insurance for the Iranian population. We tried to develop the attributes and levels of attributes according to the principles used in DCE studies. The attributes and related scenarios can be used to elicit people's preferences about health insurance in Iran and other similar contexts.

Table 2. Extracted attribute from the literature reviews and interviews and final attributes and levels

\begin{tabular}{|c|c|c|c|c|c|}
\hline \multirow[t]{2}{*}{ \# } & \multirow[t]{2}{*}{ Attribute } & \multicolumn{2}{|c|}{ Source } & \multirow{2}{*}{$\begin{array}{l}\text { Included in final design } \\
\qquad(\mathrm{y} / \mathrm{n})^{* * *}\end{array}$} & \multirow[t]{2}{*}{ Levels } \\
\hline & & Litr $^{*}$ & Interv $^{* *}$ & & \\
\hline 1 & Hospital choice & $\bullet$ & • & $\mathrm{n}$ & \\
\hline 2 & Monthly premium & $\bullet$ & • & $\mathrm{y}$ & 250000/ 350000/450000Iranian Rials \\
\hline 3 & Cost per Dr. visit & • & & $\mathrm{n}$ & \\
\hline 4 & Benefits for prescription Drugs & • & • & $\mathrm{n}$ & \\
\hline 5 & Choice of drug (generic/ brand) & • & • & $\mathrm{n}$ & \\
\hline 6 & Preventive care benefits (Wellness visits) & • & • & $\mathrm{n}$ & \\
\hline 7 & Dental coverage & • & • & $\mathrm{y}$ & $40 / 70$ percent of total expenses \\
\hline 8 & Vision coverage & • & & $\mathrm{n}$ & \\
\hline 9 & Inpatient benefits & • & • & $\mathrm{y}$ & $50 / 70 / 90$ percent of total expenses \\
\hline 10 & Rehabilitation/ Physical therapy Benefits & • & • & $\mathrm{y}$ & $50 / 70 / 90$ percent of total expenses \\
\hline 11 & Hospital wait & $\bullet$ & & $\mathrm{n}$ & \\
\hline 12 & $\begin{array}{l}\text { An average waiting time for out-patient Depart- } \\
\text { ment }\end{array}$ & • & & $\mathrm{n}$ & \\
\hline 13 & Availability of medicines & • & • & $\mathrm{n}$ & \\
\hline 14 & Transport & • & & $\mathrm{n}$ & \\
\hline 15 & Long- term care & • & • & $\mathrm{y}$ & $50 / 70 / 90$ percent of total expenses \\
\hline 16 & Quality of care (inpatient/outpatient) & • & • & $\mathrm{n}$ & \\
\hline 17 & $\begin{array}{l}\text { Benefits for specific diseases (such as cancer and } \\
\text { renal diseases) }\end{array}$ & & • & $\mathrm{n}$ & \\
\hline 18 & counseling and psychiatric Benefits & & • & $\mathrm{n}$ & \\
\hline 19 & infertility services benefits & & • & $\mathrm{n}$ & \\
\hline 20 & maternity benefits & & • & $\mathrm{n}$ & \\
\hline 21 & Public hospitals benefits & & • & $\mathrm{y}$ & $60 / 90$ percent of total expenses \\
\hline 22 & Private hospitals benefits & & • & $\mathrm{y}$ & $50 / 70 / 90$ percent of total expenses \\
\hline 23 & Number of inpatient and outpatient centers & $\bullet$ & • & $\mathrm{n}$ & \\
\hline 24 & Benefits for medical devices (Ortez, Protez, etc) & & • & $\mathrm{y}$ & $60 / 90$ percent of total expenses \\
\hline 25 & Paraclinical benefits & • & $\bullet$ & $\mathrm{y}$ & $50 / 70 / 90$ percent of total expenses \\
\hline 26 & Screening tests & & $\bullet$ & $\mathrm{n}$ & \\
\hline
\end{tabular}


Most DCE studies determine attributes based on literature review and qualitative studies using FGD and interviews $(23,27,29,43)$. Similarly, the facts derived from the review of literature helped us develop and adjust the candidate list of attributes. COAST et al. stated that interview is helpful and can strengthen ways for developing attributes. It can also reduce the possibility of misspecification of attributes if the sample is selected purposively and correctly (44).

Asking indirect questions about attributes allows the experts to express their opinions fully and avoid bias about specific characteristics of health insurance. As it was expected, the findings from the interview of the experts assisted in understanding the relative importance of each feature and the dominant and unimportant characteristics of health insurance (44). Other studies also used expert interviews and opinions to extract attributes and levels $(15,27)$. Most of the attributes included in final design in our study were extracted from both the reviews and literature interviews. Using literature review only to develop attributes may be misleading. On the other hand, using expert opinion to determine attribute-levels can provide good framework. Again the attribute-levels with higher ranks are not necessarily better to be included in the final design. Therefore, the 2 methods can be complementary to extract the needed attributes. It is also important for a research team to decide about the final levels according to the aims of the study and technical restrictions of DCE methodology.

Van den berg et al. (31) considered preventive care in their study. Another study (33) included wellness visits as an attributes of managed care organization. The primary services are public in Iran. Hence, the government is the main provider of the services, such as prenatal care and vaccinations free of charge both in rural and urban areas $(39,45)$. However, both the public and private sectors have an active role in providing secondary and tertiary levels services. The private sector usually provides services in urban areas $(39,45)$. Many of the secondary and tertiary health care services are expensive and the users face high OOP. One of the goals of the $5^{\text {th }}$ Iran Development Plan (time span 2011 to 2015) was to reduce these high OOP payments (46). However, before the implementation of the health sector evolution plan in Iran in May, 2014 , the OOP accounted for more than $50 \%$ of the total health care expenditures, and health insurance did not have any effective role in the financial protection of the households (47). Thus, reducing OOP payments for health expenditures is one of the main concerns of the policymakers. The proper insurance coverage for health services can be facilitated to reach this goal. Therefore, the coverage of necessary health services was considered as one of the important attributes from the perspective of the experts.

The experts in our study believed that hospital admission is one of the costly services that require health insurance coverage. Evidence from another study reported the association between inpatient care and high OOP and catastrophic expenditures (45). The private sector is believed to provide better quality services, and the insurance cover- age to private sector can lead many people to choose insurance. Meanwhile, some evidence suggests hospitalization in private hospitals raises the probability of catastrophic expenditures (48). Therefore, our study considered the coverage of inpatient care in public and private sectors as 2 separate attributes. The preferences of people about private services can be seen as their perception about quality service.

Papar (35) considered outpatient expenses as one of the attributes to elicit WTP for voluntary health insurance in Thailand. Our study also included this attribute for the context of Iran. The limited insurance coverage of outpatient services and dental care were identified as the weaknesses of the current insurance system in Iran. Therefore, people who use these services will be forced to challenge the high OOP. A previous study in Iran also found catastrophic health expenditures of inpatient and dental care services (45). This indicates that the insurance coverage for these services is not sufficient. The inclusion of this attribute to the final attribute design can help elicit the preferences of people about insurance coverage and plan health insurance. Evidence on the coverage of these services indicated that the proper coverage can significantly influence the insured to select health insurance and seek needed services (49).

Another study considered paraclinical services as levels of health services benefit package attributes. Our findings revealed that the current insurance coverage of paraclinical, rehabilitation, and benefits for medical devices (Ortez, Protez, etc.) services in Iran is not sufficient. Thus, improving insurance coverage to address the gap in these services could remarkably affect WTP for health insurance in the context. Hence, we found these attributes to be appropriate for inclusion in the final attribute design to evaluate preferences of the public.

The experts stated that long-term care is an important attribute in Iran because of the rising number of the elderly population in the country. In Iran, the proportion of elderly population is increasing and the long-term care can impose high costs on households and the society in general (50). An improvement in life expectancy is likely to be associated with high cost of treatment for chronic diseases (51). Another country included long-term care in the final design of its health insurance attributes (35). This can have an important positive influence on purchasing health insurance and on the WTP of people for health insurance. Furthermore, similar studies $(19,31)$ considered the premium/price as the main attribute of health insurance, which can help to estimate the WTP to attributes. Our study also considered premium/price as one of the main attributes of the basic health insurance in Iran.

\section{Conclusions}

The findings of our study indicated that the attributes related to service benefit packages and premiums as the most important for eliciting the preferences of people with health insurance in Iran. The basic health care services are favored priority than other higher services, such as infertility services and screening tests. Thus, the policymakers and health insurance organizations need to consider the 
next priority services to be included in the insurance coverage. The identified attributes are considered supportive to evaluate people's preferences and willingness to pay for attributes. The evidence obtained from such studies can also be helpful in informing the policymakers and making improvements in benefit packages accordingly.

\section{Acknowledgments}

This paper was part of the PhD thesis of Ali Kazemi Karyani. This research was funded by Tehran University of Medical Sciences (fund No. 29725). Also, the first author received a grant from the Social Security Research Institute (fund No.395002684). The authors would like to thank Tehran University of Medical Sciences and Social Security Research Institute for their financial support. Also, the authors thank the Social Security Insurance Organization (SSIO) and Iran Health Insurance Organization (IHIO) for their support in data gathering process.

\section{Conflict of Interests}

The authors declare that they have no competing interests.

\section{References}

1. Ryan M, Gerard K. Using discrete choice experiments to value health care programmes: current practice and future research reflections. Appl Health Econ Health Policy. 2003;2(1):55-64.

2. Bansback N, Brazier J, Tsuchiya A, Anis A. Using a discrete choice experiment to estimate health state utility values. J Health Econ. 2012;31(1):306-18.

3. Chong C, Naglie G, Krahn M, editors. Do clinical practice guidelines incorporate evidence on patient preferences. Boston, MA: 28th Annual Meeting of the Society for Medical Decision Making; 2006.

4. Bridges JF, Hauber AB, Marshall D, Lloyd A, Prosser LA, Regier DA, et al. Conjoint analysis applications in health--a checklist: a report of the ISPOR Good Research Practices for Conjoint Analysis Task Force. Value in health. 2011;14(4):403-13.

5. Lagarde M, Blaauw D. A review of the application and contribution of discrete choice experiments to inform human resources policy interventions. Hum Resour Health. 2009;7:62.

6. Nanna A. Health insurance in developing countries: willingness to pay for health insurance in Thailand using discrete choice experiment methods: Curtin University, Centre for International Health; 2011.

7. de Bekker-Grob EW, Ryan M, Gerard K. Discrete choice experiments in health economics: a review of the literature. J Health Econ. 2012;21(2):145-72.

8. Kjær T. A review of the discrete choice experiment-with emphasis on its application in health care. 1 ed: Syddansk Universitet Denmark; 2005 .

9. Norman R, Viney R, Brazier J, Burgess L, Cronin P, King M, et al. Valuing SF-6D health states using a discrete choice experiment. Med Decis Making. 2013;34(6):773-86.

10. Lagarde M, Blaauw D. A review of the application and contribution of discrete choice experiments to inform human resources policy interventions. Hum Resour Health. 2009;7(62):62.

11. Ryan M, Farrar S. Using conjoint analysis to elicit preferences for health care. BMJ. 2000;320(7248):1530-3.

12. Lancsar E, Louviere J. Conducting discrete choice experiments to inform healthcare decision making: a user's guide. Pharmacoeconomics. 2008;26(8):661-77.

13. Gerard K, Shanahan M, Louviere J. Using stated preference discrete choice modelling to inform health care decision-making: A pilot study of breast screening participation. J Appl Econ . 2003;35(9):1073-85.

14. Howard K, Salkeld G. Does attribute framing in discrete choice experiments influence willingness to pay? Results from a discrete choice experiment in screening for colorectal cancer. Value Health. 2009;12(2):354-63.

15. Hall J, Kenny P, King M, Louviere J, Viney R, Yeoh A. Using stated preference discrete choice modelling to evaluate the introduction of varicella vaccination. J Health Econ. 2002;11(5):457-65.

16. Sculpher M, Bryan S, Fry P, de Winter P, Payne H, Emberton M. Patients' preferences for the management of non-metastatic prostate cancer: discrete choice experiment. Bmj. 2004;328(7436):382.

17. Kjær T, Gyrd-Hansen D. Preference heterogeneity and choice of cardiac rehabilitation program: Results from a discrete choice experiment. Health Policy. 2008;85(1):124-32.

18. Youngkong S, Baltussen R, Tantivess S, Koolman X, Teerawattananon Y. Criteria for priority setting of HIV/AIDS interventions in Thailand: a discrete choice experiment. BMC Health Serv Res. 2010;10(1):197.

19. Abiiro GA, Torbica A, Kwalamasa K, De Allegri M. Eliciting community preferences for complementary micro health insurance: a discrete choice experiment in rural Malawi. Soc Sci Med. 2014;120:160-8.

20. Rafiei S, Arab M, Rashidian A, Mahmoudi M, Rahimi-Movaghar V. Policy interventions to improve rural retention among neurosurgeons in Iran: A discrete choice experiment. Iran J Neurol. 2015;14(4):211-8.

21. Ebadi J, Mehrara M, Tameli S, Sobhanian H. A Survey on Preferences and Factors Influencing the Decision of the Physicians Working in Public Centers of Tehran University of Medical Sciences to enter Family Physician [persian]. Journal of Health Administration. 2014;17(56):95-107.

22. Ezatabadi MR, Rashidian A, Shariati M, Foroushani AR, Sari AA. Using Conjoint Analysis to Elicit GPs' Preferences for Family Physician Contracts: A Case Study in Iran. Iran Red Crescent Med J. 2016(In Press).

23. Abiiro GA, Leppert G, Mbera GB, Robyn PJ, De Allegri M. Developing attributes and attribute-levels for a discrete choice experiment on micro health insurance in rural Malawi. BMC Health Serv Res. 2014;14(1):235.

24. Asgary A, Willis K, Taghvaei AA, Rafeian M. Estimating rural households' willingness to pay for health insurance. Eur J Health Econ. 2004;5(3):209-15.

25. Nosratnejad S, Rashidian A, Mehrara M, Akbari Sari A, Mahdavi G, Moeini M. Willingness to pay for the social health insurance in Iran. Glob J Health Sci. 2014;6(5):154-63.

26. Nosratnejad S, Rashidian A, Dror DM. Systematic Review of Willingness to Pay for Health Insurance in Low and Middle Income Countries. PLoS One. 2016;11(6):e157470.

27. Ryan M, Kolstad J, Rockers P, Dolea C. How to conduct a discrete choice experiment for health workforce recruitment and retention in remote and rural areas: a user guide with case studies. 1 ed: World Health Organization \& CapacityPlus: World Bank; 2012. 94 p.

28. Bridges JF. Stated preference methods in health care evaluation: an emerging methodological paradigm in health economics. Appl Health Econ Health Policy. 2003;2(4):213-24.

29. de Bekker-Grob EW, Bliemer MC, Donkers B, Essink-Bot ML, Korfage IJ, Roobol MJ, et al. Patients' and urologists' preferences for prostate cancer treatment: a discrete choice experiment. Br J Cancer. 2013;109(3):633-40.

30. Coast J, Horrocks S. Developing attributes and levels for discrete choice experiments using qualitative methods. J Health Serv Res Policy. 2007;12(1):25-30.

31. van den Berg B, Van Dommelen P, Stam P, Laske-Aldershof T, Buchmueller T, Schut FT. Preferences and choices for care and health insurance. Soc Sci Med. 2008;66(12):2448-59.

32. Guest G, Bunce A, Johnson L. How many interviews are enough? An experiment with data saturation and variability. Field methods. 2006;18(1):59-82.

33. Gates R, McDaniel C, Braunsberger K. Modeling consumer health plan choice behavior to improve customer value and health plan market share. J Bus Res. 2000;48(3):247-57.

34. Kruk ME, Rockers PC, Tornorlah Varpilah S, Macauley R. Population preferences for health care in liberia: insights for rebuilding a health system. Health Serv Res. 2011;46(6pt2):2057-78.

35. Papar K. Willingness to Pay for Voluntary Health Insurance after Retirement in Thailand. NIDA Development Journal. 2014;54(2):11757.

36. van der Haar S. Demand and willingness-to-pay for health insurance and health cooperatives in Nepal: a discrete choice experiment: Wageningen University and Research Centre; 2013.

37. Kerssens JJ, Groenewegen PP. Consumer preferences in social health insurance. Eur J Health Econ. 2005;6(1):8-15.

38. Becker K, Zweifel P. Age and choice in health insurance: evidence 
from a discrete choice experiment. The patient. 2008;1(1):27-40.

39. Hershey JC, Kunreuther H, Schwartz JS, Williams SV. Health insurance under competition: Would people choose what is expected? Inquiry. 1984;21(4):349-60.

40. Vroomen JM, Zweifel P. Preferences for health insurance and health status: does it matter whether you are Dutch or German? Eur J Health Econ. 2011;12(1):87-95.

41. Kruk ME, Rockers PC, Tornorlah Varpilah S, Macauley R. Population preferences for health care in liberia: insights for rebuilding a health system. Health Serv Res. 2011;46(6pt2):2057-78.

42. Kuhfeld W. Marketing research methods in SAS. 2010. ed2013. 1309 p.

43. Rao KD, Ryan M, Shroff Z, Vujicic M, Ramani S, Berman P. Rural clinician scarcity and job preferences of doctors and nurses in India: a discrete choice experiment. PLoS One. 2013;8(12):e82984.

44. Coast J, Al-Janabi H, Sutton EJ, Horrocks SA, Vosper AJ, Swancutt $\mathrm{DR}$, et al. Using qualitative methods for attribute development for discrete choice experiments: issues and recommendations. J Health Econ. 2012;21(6):730-41.

45. Kavosi Z, Rashidian A, Pourreza A, Majdzadeh R, Pourmalek F, Hosseinpour AR, et al. Inequality in household catastrophic health care expenditure in a low-income society of Iran. Health Policy Plan. 2012;27(7):613-23.

46. Fourth Planning and Management Organization of the Islamic Republic of Iran, 20. ' Five-Year Economic, Social and Cultural Development Plan of the Islamic Republic of Iran (2011-2015). Tehran: Deputy for Research, Development and Codification of Laws and Regulations.

47. Organization WH. Health system profile, Islamic Republic of Iran Regional Health Systems Observatory, WHO Eastern Mediterranean Regional Office. 2006.

48. Hajizadeh M, Nghiem HS. Out-of-pocket expenditures for hospital care in Iran: who is at risk of incurring catastrophic payments? Int $\mathrm{J}$ Health Care Finance Econ. 2011;11(4):267-85.

49. Alavian SM. Determinants of seeking needed outpatient care in Iran: results from a national health services utilization survey. Arch Iran Med. 2007;10(4):439-45.

50. Tofighi S, Zaboli R, Mahdavi MRV, Moradi M, Rezapoor A, Golmakani MM, et al. The Healthcare Costs in the Aging Based on Data from the Urban Health Equity Assessment and Response Tool Project in Tehran, Iran (UHEART-2). IJMR. 2015;2(1):201-7.

51. Spillman BC, Lubitz J. The effect of longevity on spending for acute and long-term care. N Engl J Med. 2000;342(19):1409-15. 